https://helda.helsinki.fi

\title{
Anti-heat island circulations and low-level jets on a sea gulf
}

\section{Savijärvi, Hannu}

2011

Savijärvi , H 2011, ' Anti-heat island circulations and low-level jets on a sea gulf ' , Tellus.

Series A: Dynamic Meteorology and Oceanography , vol. 63 , no. 5 , pp. 1007-1013 . https://doi.org/10.1111/j.1600-

http://hdl.handle.net/10138/162037

https://doi.org/10.1111/j.1600-0870.2011.00531.x

cc_by

publishedVersion

Downloaded from Helda, University of Helsinki institutional repository.

This is an electronic reprint of the original article.

This reprint may differ from the original in pagination and typographic detail.

Please cite the original version. 


\title{
Anti-heat island circulations and low-level jets on a sea gulf
}

\author{
By H. I. S AVIJ ÄRVI*， Department of Physics, 00014 University of Helsinki, Finland \\ (Manuscript received 1 October 2010; in final form 26 May 2011)
}

\begin{abstract}
A two-dimensional fine-scale atmospheric model was set across an idealized 80-km-wide east-west sea gulf at $60^{\circ} \mathrm{N}$ ('Gulf of Finland'). During a moderate south-easterly basic flow in overcast early summer conditions, a robust low-level jet (LLJ) is formed, with diverging and relatively strong afternoon surface easterlies blowing along the cool gulf. The LLJ is caused primarily by inertial oscillation in space-time due to the large difference in roughness and stability over the land and the sea, but the surface easterlies are also enhanced by an anti-heat island circulation triggered by the slant basic flow across the cool sea gulf. The dynamics and details of the anti-heat island circulation are discussed. With warmer waters the primary LLJ relaxes and the anti-heat island circulation ceases while the enhanced vertical mixing still maintains strong surface winds over the warm sea, but with reduced cross-isobar angles. Sunny conditions enhance convection over land and may induce sea breezes. These may reinforce the LLJ and the associated surface easterlies over the sea.
\end{abstract}

\section{Introduction}

Local winds and mesoscale wind systems respond strongly and nonlinearly to changes in the topography, roughness and temperature at the surface (e.g. Atkinson, 1981; Stull, 1988; Pielke, 2002). These properties vary strongly across coastlines. The small-scale coastal surface wind changes due to contrasts in roughness and surface temperature were studied in Savijärvi (2004), whereas the meso-scale summertime winds over a flattopography sea gulf region, such as the Gulf of Finland, were the subject in Savijärvi et al. (2005, SNT from now on). Two atmospheric models were employed in these studies: a twodimensional (2-D) high-resolution University of Helsinki (UH) research model and a 3-D operational model (HIRLAM), the results agreeing with several observational north-European data sets. The UH model has also been used to study low- and highlatitude sea breezes (e.g. Savijärvi, 1995, 1997; Gahmberg et al., 2010), as well as flows around urban and tropical heat islands (Savijärvi and Jin, 2001; Savijärvi and Matthews, 2004), the results agreeing with various campaign aircraft, ship and landbased observations and with the linear model results of the heat island circulation (HIC).

We return here to the most interesting case of SNT, where during a moderate south-easterly (SE) basic flow a low-level

\footnotetext{
* Corresponding author.

e-mail: hannu.savijarvi@helsinki.fi

DOI: $10.1111 /$ j.1600-0870.2011.00531.x
}

jet (LLJ) is formed near the north coast of the Gulf of Finland. The Finnish and Estonian duty forecasters and ship operators are familiar with the associated relatively strong along-shore surface easterlies at the sea, which are not well predicted by large-scale models and have remained somewhat puzzling. Here idealized high-resolution 2-D simulations are made about this case together with sensitivity studies to find out the essential mechanisms for its dynamics. Special attention is given to the sea surface temperature (SST), because a relatively warm or cold sea gulf may create HIC effects. It is shown that such effects exist and enhance the surface easterlies in overcast conditions, whereas in sunny conditions sea breezes may further complicate the situation.

HICs triggered by basic flow over a warm surface strip have been extensively studied with linear analytic models (e.g. Olfe and Lee, 1971; Hsu, 1987; Baik, 1992; Lin, 2007). These studies have shown that non-hydrostatic effects are insignificant for a strip wider than about $5 \mathrm{~km}$, so for the roughly 80- to 100-km-wide Gulf of Finland (Fig. 1) the hydrostatic UH model is an appropriate tool. The model includes good-quality physics; a new local turbulence parametrization for stable conditions is introduced in Section 2. Based on model experiments, the less extensively studied dynamics of an anti-HIC, created by flow over a cold strip, is discussed in Section 4 and compared with the warm sea case in Section 5, with conclusions given in Section 6.

Figure 1 shows a map of the Gulf of Finland with an SE flow case commented in Section 3. An idealized east-west aligned 


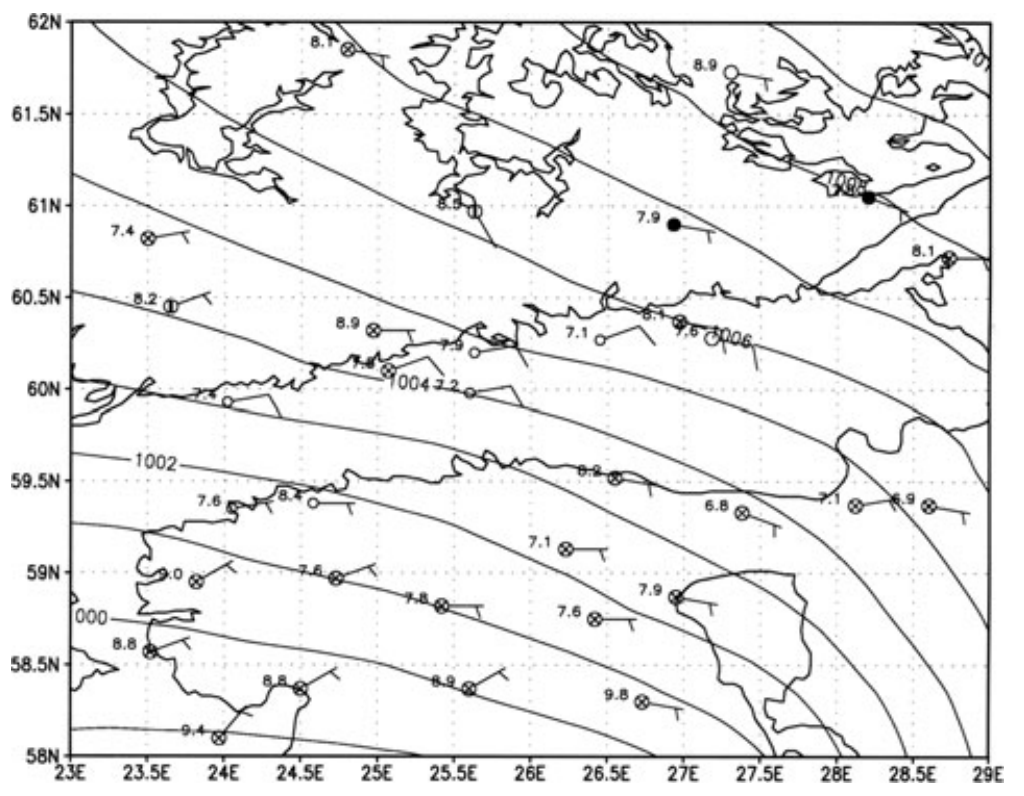

Fig. 1. The Gulf of Finland along $60^{\circ} \mathrm{N}$ (Finland in the north, Estonia in the south) and the HIRLAM surface pressure analysis 26 May 200606 UTC (09 local time) with observed winds and $2 \mathrm{~m}$ temperatures. 80-km-wide gulf was used in SNT and in Gahmberg et al. (2010) for convenience, and this will also be assumed here. The model results are, however, valid for any orientation of a gulf or a long lake. The 2-D model is set across the gulf, $x$ increasing to the north, so its wind component $u$ is across, and $v$ along, the gulf. This facilitates easy comparison with the linear model results, where $u$ stands for the flow component across a warm or a cold strip in an arbitrary horizontal orientation.

\section{The model and experiments}

The University of Helsinki 2-D sigma coordinate model is applied here in the same resolution ( $2 \mathrm{~km}$ horizontal grid length) across a Gulf of Finland-like sea at $60^{\circ} \mathrm{N}$ (Fig. 1) as in SNT. The model dynamics is based on Alpert et al. (1982). The large-scale pressure gradient, constant in time and space in the present idealized experiments, is given in the form of a constant geostrophic wind vector $\mathbf{V}_{\mathrm{g}}$. The long-wave radiative transfer is based on a six-band, and the short-wave (SW) transfer on a four-band scheme. Surface-air exchanges and turbulence are coherently represented by a Blackadar-type first-order closure. The stability functions follow the Dyer-Businger forms for unstable layers, whereas for all stable layers (Richardson number $\mathrm{Ri}>0$ ) the local formulation $f(\mathrm{Ri})=\left(1+5 \mathrm{Ri}+44 \mathrm{Ri}^{2}\right)^{-2}$ is adopted after Savijärvi (2009). This formulation is based on an asymptotic theory (Zilitinkevich et al., 2002), is quite close to the widely adopted purely empirical form of Beljaars and Holtslag (1991), and produces good simulations even in the extremely stable Antarctic polar night (Savijärvi, 2009). The same $f(\mathrm{Ri})$ are used at all heights, the surface transfers and the surface layer thereby being an integral part of the planetary boundary layer (PBL). More information about the model is given in SNT and in the references therein.
In the present experiments there are 132 horizontal grid points at 25 sigma levels. The model top is at about $7 \mathrm{~km}$ and the lowest points are at $2,10,25 \ldots$ above the surface, the sigma vertical velocities vanishing at the top and at the surface. There is flat, rough, forested land $\left(z_{0 \mathrm{~m}}=50 \mathrm{~cm}\right)$ surrounding an $80-\mathrm{km}$-wide sea strip $\left(z_{0 \mathrm{~m}}=0.1 \mathrm{~mm}\right.$, grid points $\left.40-80\right)$. As a reference case a typical June day with $\mathbf{V}_{\mathrm{g}}$ of $10 \mathrm{~ms}^{-1}$ from SE is simulated, starting from midnight with $13^{\circ} \mathrm{C}$ at the surface and soil with a lapse rate of $6.5 \mathrm{~K} \mathrm{~km}^{-1}$ and $50 \%$ relative humidity. The SST is fixed to the typical observed cool mid-June value of the Gulf of Finland $\left(13^{\circ} \mathrm{C}\right)$, whereas the diurnal cycle of the surface temperature is predicted in each land point via a forcerestore scheme with $c_{\mathrm{GA}}$ of $12 \times 10^{4} \mathrm{~J} \mathrm{~m}^{-2} \mathrm{~K}^{-1}$ (Stull, 1988). The sky is kept overcast by having (artificially) a thick midtroposphere cloud with SW transmissivity of 0.2 to exclude all sea breeze effects.

In Sections 3 and 4, sensitivity experiments are made concerning the width of the sea channel and the horizontal differences in the surface temperature and roughness, whereas in Section 5 the late summer situation with a higher SST $\left(18^{\circ} \mathrm{C}\right)$ is considered, all during overcast conditions. The clear-sky (sea breeze) aspects are briefly discussed in the end of Section 5 .

\section{South-easterly flow during early summer}

Figure 2 presents the key cross sections from the reference simulation for the afternoon, 1500 local solar time (15 LT). The sky is overcast and a moderate prevailing wind $\mathbf{V}_{\mathrm{g}}$ of $10 \mathrm{~ms}^{-1}$ blows from SE, that is $\left(u_{g}, v_{g}\right)=(+7.1,+7.1) \mathrm{ms}^{-1}$ in our model framework, where $x$ increases to the north and $y$ to the west. The afternoon $\theta$-field indicates a well-mixed boundary layer over the windy upstream land area ('Estonia', left in Fig. 2) with $2 \mathrm{~m}$ temperatures of about $16^{\circ} \mathrm{C}$, a typical cloudy summer afternoon 

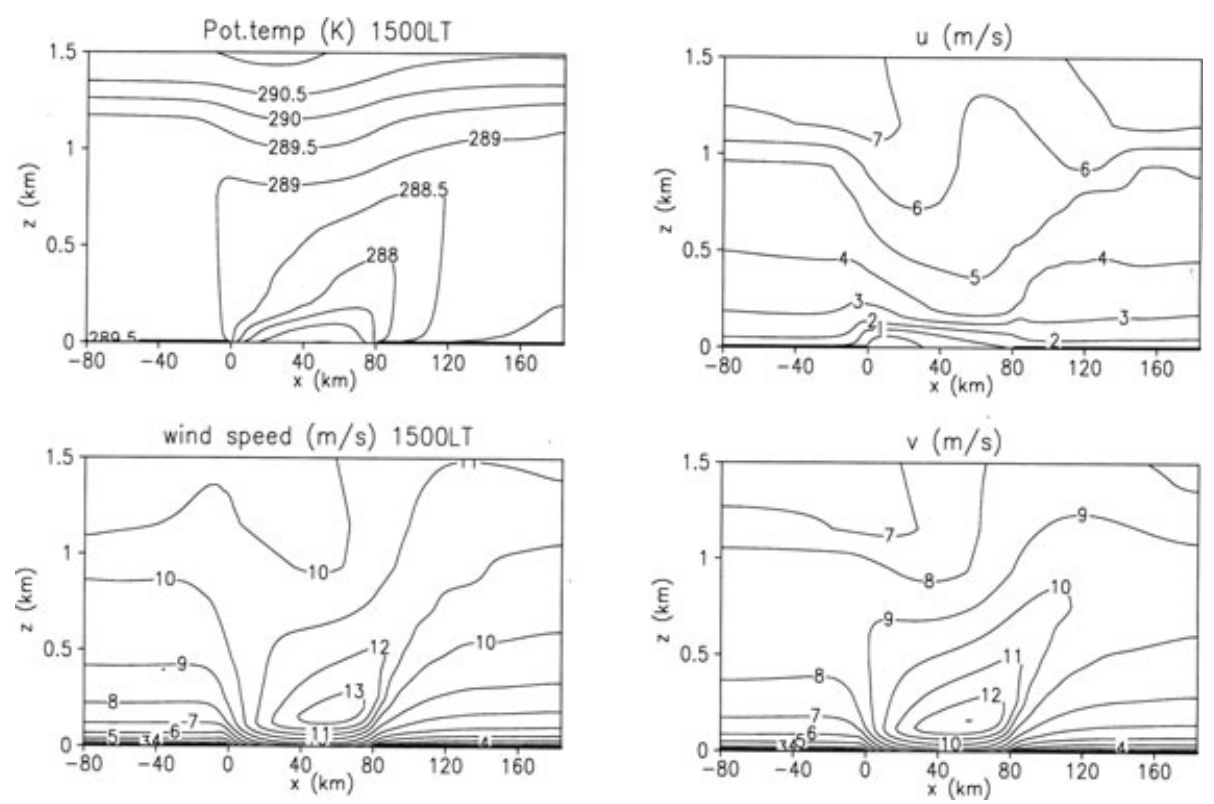

Fig. 2. Cross sections at $15 \mathrm{LT}$ across an 80 -km-wide east-west sea gulf at $60^{\circ} \mathrm{N} . x(\mathrm{~km})$ is to the north with origo at the south coast. Overcast June day simulation, $\Delta x=2 \mathrm{~km}$, cool sea $\left(\mathrm{SST} 13^{\circ} \mathrm{C}\right), \mathbf{V}_{\mathrm{g}}$ is $10 \mathrm{~ms}^{-1}$ from the southeast.

value. The near-surface air then cools via downward turbulent heat transfer when passing over the colder gulf (SST $13^{\circ} \mathrm{C}$ ), so a shallow stable internal boundary layer (SIBL) grows downstream in Fig. 2. The wind speeds display a super-geostrophic low-level jet of $13 \mathrm{~ms}^{-1}$ at $200 \mathrm{~m}$ height (at the top of the SIBL), whereas the across-coast wind component $u$ presents small values above the rough land due to the strong surface friction over forests. Over the much smoother sea one might therefore expect to find higher values of near-surface $u$, but in contrast, negative values are seen just off the upstream coast in Fig. 2. Sea breezes are however clearly excluded because of the small $2 \mathrm{~m}$ temperature difference of $3 \mathrm{~K}$ between the land and the sea, due to the overcast conditions.

The along-coast wind component $v$ displays a maximum of $13 \mathrm{~ms}^{-1}$ at $200 \mathrm{~m}$ over the sea in Fig. 2, an increase of $84 \%$ over its geostrophic value. The main reason for this shore-parallel LLJ is inertial oscillation in space-time: as the well-mixed upstream flow from over rough land enters the smooth, cool sea, the surface friction and the strong downward mixing of momentum are drastically reduced. Hence, the ageostrophic component of the wind $\mathbf{V}_{\text {ag }}$ starts to accelerate (rotate) in latitude-dependent inertial oscillation (e.g. Smedman et al., 1995), like in the nocturnal LLJ mechanism (Blackadar, 1957; Stull, 1988). The total wind $\mathbf{V}_{\mathrm{g}}+\mathbf{V}_{\mathrm{ag}}$ becomes maximally strong after about $4 \mathrm{~h}$ rotation at $60^{\circ} \mathrm{N}$. The cross-gulf advection speed $u$ being about $4 \mathrm{~ms}^{-1}$ over the sea at $200 \mathrm{~m}$ by Fig. 2, the wind maximum is located, after $4 \mathrm{~h}$ advection, about $60 \mathrm{~km}$ off the coast, and hence close to the opposite north coast in the 80-km-wide sea gulf geography. Indeed, if the north coast is replaced by an open sea in an otherwise identical simulation, a v-maximum of $11 \mathrm{~ms}^{-1}$ is found $60 \mathrm{~km}$ off the single coastline (Fig. 3, left). On the other hand, for a gulf only $30-\mathrm{km}$ wide, the air has less time to accelerate until it again enters rough land, so the perturbation caused by the strip of cool sea remains smaller (Fig. 3, right). The inertial-LLJ and the related strong surface easterlies along the north coast during the SE basic flow are thus primarily facilitated by the suitable width (80-100 km, Fig. 1) of the Gulf of Finland. The turbulence being strongest upstream during the midday hours (due to the reduced daytime stability over land), the LLJ is at its strongest in the afternoon. Hence the results are here shown at $15 \mathrm{LT}$.

The left column of Fig. 4 depicts the 15 LT surface $(10 \mathrm{~m})$ wind vectors from the above reference cool gulf simulation, and the right column respectively a similar but warm gulf simulation to be discussed in Section 5. In the cool sea case, one may note weak surface winds over land but strong and divergent easterly flow along the sea gulf. Such a wind pattern is called 'channelling' by Finnish duty forecasters. Its reasons have been debated, but mechanical channelling is probably not involved because of the relatively flat topography, whereas sea breezes are excluded in overcast conditions.

Such a channelling wind pattern was noticed, for example on 19 May 2006 06UTC (09 local time; Fig. 1), when an approaching low-pressure centre provided mostly cloudy skies and $\mathbf{V}_{\mathrm{g}}$ of about $12 \mathrm{~ms}^{-1}$ from ESE $\left(\sim 112^{\circ}\right)$ over the Gulf of Finland. The sea (SST $6^{\circ} \mathrm{C}$ ) was $1-3 \mathrm{~K}$ colder than the air upstream. The surface winds were only about $4 \mathrm{~ms}^{-1}$ in southern Finland whereas the coastal islands reported $10-13 \mathrm{~ms}^{-1}$ (Fig. 1); the 12 LT nine-island average was $11 \mathrm{~ms}^{-1}$ from $72^{\circ}$, that is wind right along the virtual coastline. Thus, winds were modest over land while off the coast they were strong (nearly supergeostrophic) 

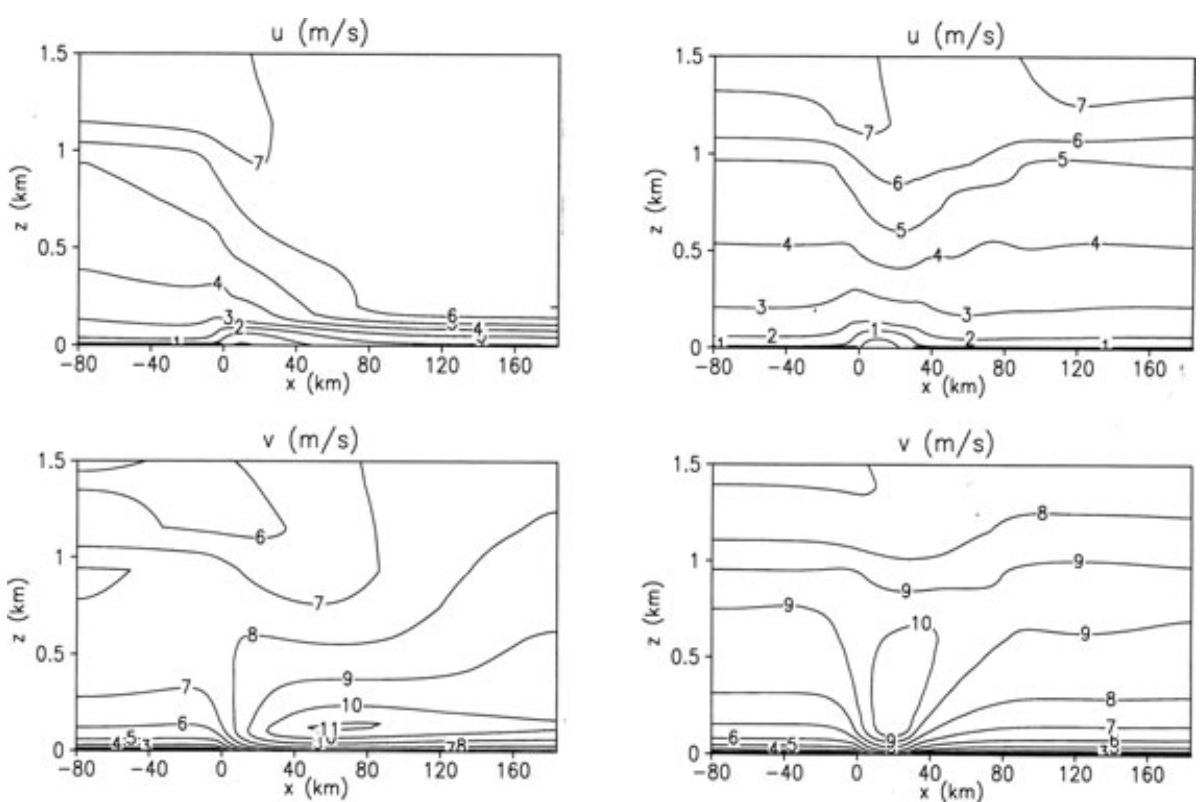

Fig. 3. As Fig. 2 but for $\mathrm{u}$ and $\mathrm{v}$ in a single coast simulation (left, 'Finland' removed), and for a gulf $30 \mathrm{~km}$ wide only (right).

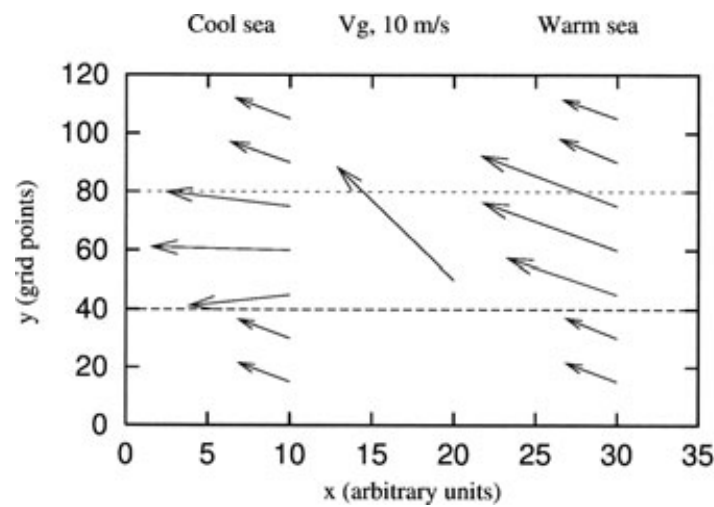

Fig. 4. Left: Map view of the $15 \mathrm{LT}$ surface winds (every $15^{\text {th }}$ grid point) from the cool sea gulf simulation with $\mathbf{V}_{\mathrm{g}}$ of $10 \mathrm{~ms}^{-1}$ from southeast (middle). Right: the same but from a warm gulf simulation. The $y$-axis (in grid point units) is to the north, the $x$-axis (in arbitrary units) to the east.

and blowing parallel with the shore, displaying quite large crossisobar angles for a smooth sea surface, such as in Fig. 4 (left). By 15 LT, the geostrophic wind turned to blow from east and the channelling episode ended with off-coast marine winds being back to their normal state of being about $70 \%$ of $\mathbf{V}_{\mathrm{g}}$ with small $\left(\sim 15^{\circ}\right)$ cross-isobar angles.

\section{Anti-HIC effects}

A warm surface spot may induce HIC. Linear models of constant basic flow blowing over a warm 10- to 100-km-wide surface strip (e.g. Olfe and Lee, 1971; Hsu, 1987) produce through enhanced sensible heat transfer a positive wind anomaly just above the warm strip and a negative anomaly aloft. Conservation of mass leads to sinking motion in front and rising motion in the rear; a warm rising plume is often observed in, for example the urban heat islands. Similarly, the less-studied case of steady flow $U$ over a cold strip leads, by linear models, to an opposite anti-HIC cell (AHIC), with $u^{\prime}<0$ just above, $u^{\prime}>0$ higher above, $w^{\prime}>0$ in front and $w^{\prime}<0$ in the rear of the cold zone. In high latitudes, an associated $v^{\prime}$ is induced via Coriolis force, $v^{\prime}$ being to the right of $u^{\prime}$ in the northern hemisphere. At $60^{\circ} \mathrm{N}$, the resulting steady state $\left|v^{\prime}\right|$ is about as large as $\left|u^{\prime}\right|$.

Figure 5 displays the 15 LT vertical velocity $w$ from the Fig. 2 reference simulation together with the difference of $u$ from its upstream boundary profile $U(z)$ undisturbed by the existence of the sea; thus $u^{\prime}=u-U(z)$, and $w^{\prime}$ equals $w$ because $W(z)$ is zero at the upstream boundary. The perturbation fields $u^{\prime}, w^{\prime}$ do display in Fig. 5 the AHIC cell features described earlier (plus weak upward propagating tilted gravity wave signatures as in the linear model results). The cell is concentrated near the upstream coast, where the driving temperature contrast between the cool gulf and the overflowing warmer air is at its largest (yet only $3 \mathrm{~K}$ ). The resulting $\mathrm{u}^{\prime}$ is $-2 \mathrm{~ms}^{-1}$ close to the upstream coast in Fig. 5, with $w$ about $1 \mathrm{~cm} \mathrm{~s}^{-1}$ at $500 \mathrm{~m}$. The roughness differences are realistically included in the 2-D model (unlike in the linear models). They lead to a rising motion above the windward (right) coast in Fig. 5 via coastal convergence. The corresponding coastal divergence and the resulting weak sinking motion above the lee coast are overwhelmed by the stronger and opposite anti-HIC in Fig. 5.

The anti-HIC of Fig. 5 resembles a weak sea breeze pattern near the lee coast. Indeed, these are related: in calm air a very 

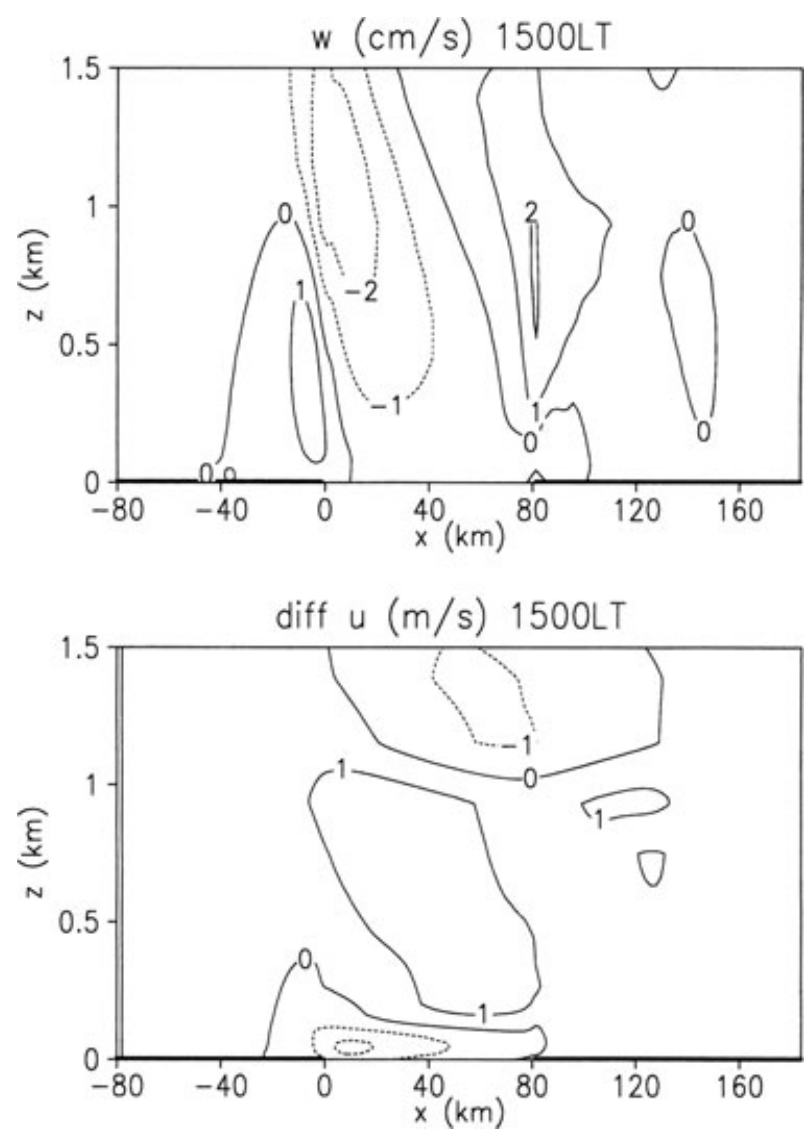

Fig. 5. As Fig. 2 but for vertical velocity $w$ and the difference in $u$ from its upstream boundary value at each height, that is wind anomalies $w^{\prime}$, $u^{\prime}$ caused by the presence of the cool sea gulf in the middle of the area.

weak sea breeze (SB) develops by the UH model over both coasts even in overcast conditions given that the sea is colder than land; in sunny conditions, the evolving breezes are of course much stronger (Section 5). A moderate basic SE flow, if now switched on slowly or suddenly, advects the windward coast $\mathrm{SB}$ cell rapidly inland in the model simulations, whereas the upstream coast $\mathrm{SB}$ cell is phase-locked to the driving temperature difference, that is above the cool sea gulf, where it evolves into the steady AHIC pattern. This is dynamically analogous to the tropical island HIC, where the steady basic flow (the trade wind) advects and phase-locks the morning SB cell of the windward coast over the sun-heated island. It then evolves into the classical HIC pattern during the day with the warm rising plume made visible by the triggered cumulus streets downstream (Savijärvi and Matthews, 2004).

We may now deduce that the channelling over the cool Gulf of Finland is partly associated with the anti-HIC. The negative values of $u^{\prime}$ above the cool sea $\left(-1 \ldots-2 \mathrm{~ms}^{-1}\right.$, Fig. 5) counteract the positive but frictionally reduced $U(z)$ to the extent that the near-surface total $u=U(z)+u^{\prime}$ is close to zero or even weakly negative off the upstream coast, as in Fig. 2. The ef- fect is reduced downstream as the air cools on the way, leading to the divergent surface wind pattern of Fig. 4. The Coriolis force-driven $v^{\prime}$, being to the right of $u^{\prime}$, is hence positive (from the east), above the cool sea. Because $\left|v^{\prime}\right| \sim\left|u^{\prime}\right|$ at $60^{\circ} \mathrm{N}$, the easterly $v^{\prime}$ associated with the anti-HIC increases the primary LLJ-driven surface easterlies at the sea by further $1-2 \mathrm{~ms}^{-1}$.

It thus appears that a cool Gulf of Finland sea surface can induce a secondary anti-heat-island circulation during a moderate basic flow from SE. This contributes to the channelling and the strong easterly surface winds. For a temperature difference larger than $3 \mathrm{~K}$, these anti-HIC features are amplified in the model, although not linearly. Thus, the channelling is most severe in spring, as observed, when the waters of the Gulf of Finland are icy cold. Furthermore, the easterly surface winds drive the gulf surface waters northward via Ekman transport. This leads to upwelling along the southern coast, bringing up deep cold water, which the Ekman transport then redistributes over the gulf. This amplifying feedback was not included in the model experiments, in which the SST was kept constant.

Some sensitivity tests were made. In a simulation, where the surface temperatures (land and SST) were kept at $13^{\circ} \mathrm{C}$ everywhere all the time, there were no thermal contrasts at the surface so no AHIC developed as can be expected. The remaining roughness difference still induced inertial oscillation, indicating a steady LLJ of $12 \mathrm{~ms}^{-1}$ near the north coast (cf. $13 \mathrm{~ms}^{-1}$ at $15 \mathrm{LT}$ in the reference simulation). But in striking contrast with Fig. 5, $u^{\prime}$ increases in this simulation over the smooth sea surface, producing the usual coastal divergence and sinking motion over the lee coast with convergence and rising motion on the windward coast as in Alestalo and Savijärvi (1985). In another test simulation, the roughness length $z_{0}$ was the same everywhere $(1 \mathrm{~mm})$ but the land surface temperatures were diurnally evolving. Here a weak afternoon LLJ of $11 \mathrm{~ms}^{-1}$ and weak surface easterlies developed at the sea unsupported by roughness contrasts, due to the reduced vertical mixing over the cool sea and the emerging but weak AHIC.

Figure 3 also presented a sensitivity study. With no opposite coast (Fig. 3, left), there is no closed AHIC and the LLJ $60 \mathrm{~km}$ off the coast is weak. With a narrow gulf (Fig. 3, right), the AHIC is present (note the negative values of $u$ over the sea) but the inertial oscillation does not have time and space enough to fully strengthen the primary LLJ until the flow again meets rough land.

\section{South-easterly flow during late summer}

Later in the summer, the Gulf of Finland waters warm up. If the SST is changed to the typical late summer value of $18^{\circ} \mathrm{C}$ in the reference simulation (everything else being the same), the cloudy-afternoon temperatures evolve to a well-mixed state throughout the PBL, with $\theta$ about $16.5^{\circ} \mathrm{C}$ (Fig. 6). The sea is thus slightly warmer than the air but because the horizontal thermal and stability contrasts remain small, no HIC is triggered. The 

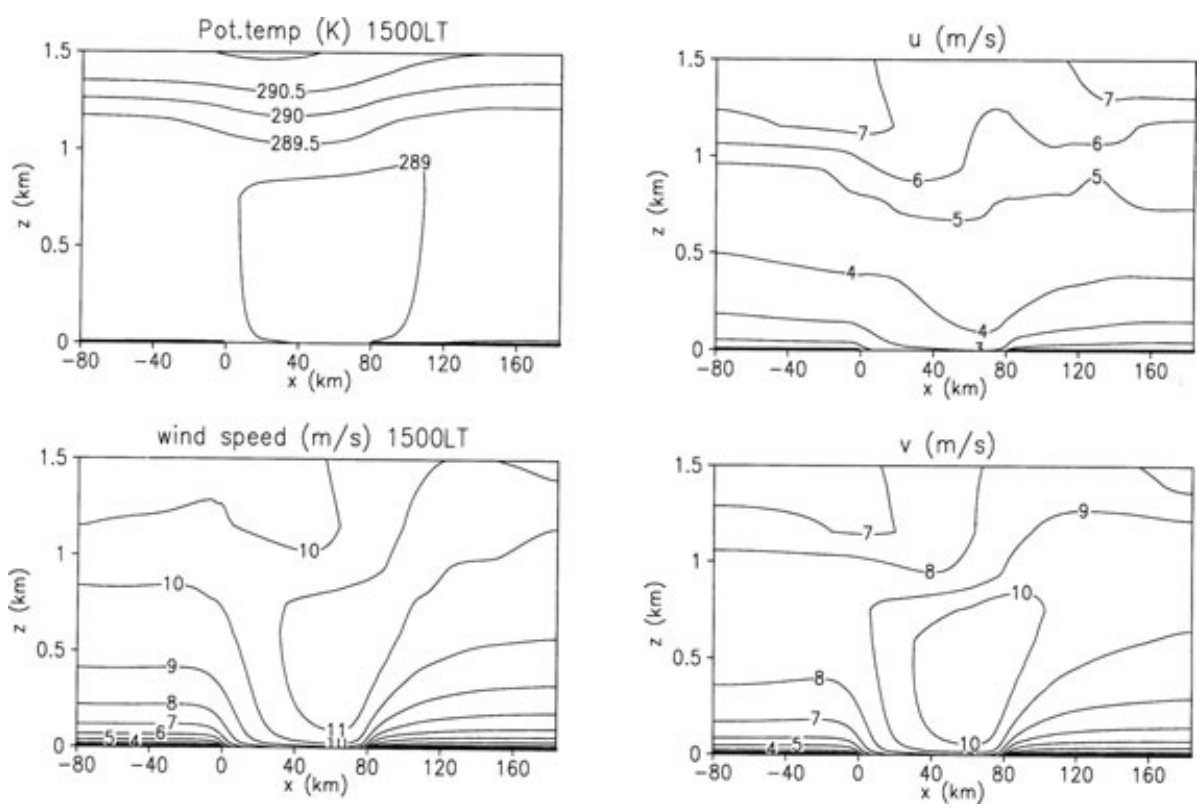

Fig. 6. As Fig. 2 but for a simulation with a warm sea surface $\left(\operatorname{SST} 18^{\circ} \mathrm{C}\right)$.

mechanical roughness difference therefore dominates the flow near the surface, wind components $u$ as well as $v$ now increasing over the smooth sea in Fig. 6. As a result, the surface wind speeds increase over the sea whereas their cross-isobar angles stay about the same as over land (Fig. 4, right).

The LLJ is still present near the north coast in Fig. 6, now mainly due to the roughness difference. It is slightly higher up and weaker than in Fig. 2. The vertical mixing of momentum is however strongly enhanced in the convective PBL over the warm sea, compared to Fig. 2 case. Hence the surface winds, downmixed from the LLJ, are relatively strong at the sea but their cross-isobar angles are characteristically smaller than in the cool sea case, due to the strong vertical mixing and the absence of the AHIC/HIC contribution. This is neatly summarized in Fig. 4, where the only difference between the two overcast SE flow experiments is the value of the associated SST of the east-west sea channel.

If the summer sky is clear instead, afternoon sea breezes may appear over both coasts of the Gulf of Finland. A weak-tomoderate wind component from land enhances the sea breeze and may advect or keep the whole SB cell evolution seaward (Estoque, 1962; Walsh, 1974; Savijärvi and Alestalo, 1988; Arritt, 1993; Pielke, 2002; Gahmberg et al., 2010). Hence easterlies may become intense in the Gulf of Finland in the afternoon and evening, if the strong north-easterly sea breezes pushed northward from the Estonian coast by the SE basic flow get combined with the simultaneous inertial-LLJ and its surface easterlies. A case study of a clear day (29 August 1997) with a $V_{g}$ of about $10 \mathrm{~ms}^{-1}$ from ESE was presented in SNT, indicating an easterly LLJ of $17 \mathrm{~ms}^{-1}$ over the Finnish coast, with super-geostrophic surface easterlies of up to $14 \mathrm{~ms}^{-1}$ observed on the coastal islands. High-resolution HIRLAM and UH model simulations produced wind fields close to those observed, with visible sea breeze signatures.

\section{Conclusions}

Cases of relatively strong coastal winds were studied on a sea gulf, a channel or a large lake by making experiments with a high-resolution 2-D mesoscale model set across an idealized east-west $80-\mathrm{km}$-wide sea at $60^{\circ} \mathrm{N}$ ('Gulf of Finland'). The model was equipped with a novel turbulence scheme for stable conditions. Its results appear to agree with observations in the case studies discussed.

During overcast cool sea conditions of early summer, a moderate prevailing south-easterly flow $\left(V_{\mathrm{g}}=10 \mathrm{~ms}^{-1}\right)$ produced an easterly alongshore afternoon low-level jet of $13 \mathrm{~ms}^{-1}$ over the gulf at about $200 \mathrm{~m}$ height. The jet is basically due to inertial oscillation in space-time caused by the abrupt change in roughness and stability at the coast, but it appears to be augmented by antiHIC effects. These strengthen ('channel') the surface winds to $90-100 \%$ of $V_{\mathrm{g}}$ over the sea in a divergent shore-parallel easterly flow pattern. The anti-HIC with rising motion over the upstream coast, the LLJ and the divergent ('channelling') surface flow features are all enhanced by cold seawater, as during spring and early summer. The sensitivities and dynamics of the associated anti-HIC were discussed based on numerical experimenting.

The warm waters of late summer damp the anti-HIC, whereas the vertical mixing of momentum is enhanced over the warm sea. Hence, the inertial-LLJ associated with the south-easterly basic flow is weaker than in the cool sea simulation but the surface winds over the warm sea are nevertheless relatively strong. 
Their cross-isobar angle is, however, much smaller than in the cool sea case. In clear-sky summer conditions, the LLJ is further strengthened by sea breezes, provided the basic SE flow is not too strong. This can lead to supergeostrophic shore-parallel surface easterlies along the north coast during the afternoon and evening.

\section{Acknowledgments}

This work is related to the Academy of Finland grants 54084, 167836, 210794, and to the EU program MEXC-CT-2003509742. Calculations were made in the Centre of Scientific Computing, Espoo. The comments by the reviewers helped to clarify the text.

\section{References}

Alestalo, M. and Savijärvi, H. 1985. Mesoscale circulations in a hydrostatic model: coastal convergence and orographic lifting. Tellus 37A, $156-162$.

Alpert, P., Cohen, A., Neumann, J. and Doron, E. 1982. A model simulation of the summer circulation from the eastern Mediterranean past Lake Kinneret in the Jordan Valley. Mon. Wea. Rev. 110, 994-1006.

Arritt, R. W. 1993. Effects of the large-scale flow on characteristic features of the sea breeze. J. Appl. Meteor. 32, 116-125.

Atkinson, B. W. 1981. Mesoscale Atmospheric Circulations. Academic Press, London, UK, 496 pp.

Baik, J.-J. 1992. Response of a stably stratified atmosphere to low-level heating - an application to the heat island problem. J. Appl. Meteorol. 31, 291-303.

Beljaars, A. and Holtslag, A. A. M. 1991. Flux parameterization over land surfaces for atmospheric models. J. Appl. Meteor. 30, 327-341.

Blackadar, A. K. 1957. Boundary-layer wind maxima and their significance for the growth of nocturnal inversion. Bull. Am. Meteor. Soc. 38, 283-290.

Estoque, M. A. 1962. The sea breeze as a function of the prevailing synoptic situation. J. Atmos. Sci. 19, 244-250.
Gahmberg, M., Savijärvi, H. and Leskinen, M. 2010. The influence of synoptic scale flow on sea breeze induced surface winds and calm zones. Tellus 62A, 209-217.

Hsu, H.-M. 1987. Study of linear steady atmospheric flow above a finite surface heating. J. Atmos. Sci. 44, 186-199.

Lin, Y.-L. 2007. Mesoscale Dynamics. Cambridge University Press, New York.

Olfe, D. B. and Lee, R. L. 1971. Linearized calculations of urban heat island convection effects. J. Atmos. Sci. 28, 1374-1388.

Pielke, R. A. 2002. Mesoscale Meteorological Modelling, 2nd Edition. Academic Press, San Diego.

Savijärvi, H. and Alestalo, M. 1988. The sea breeze over a lake or gulf as the function of the prevailing flow. Beitr. Phys. Atmos. 61, 98-104.

Savijärvi, H. 1995. Sea breeze effects on large-scale atmospheric flow. Beitr. Phys. Atmos. 68, 335-344.

Savijärvi, H. 1997. Diurnal winds around Lake Tanganyika. Quart. J. Roy. Meteor. Soc. 123, 901-918.

Savijärvi, H. 2004. Model predictions of coastal winds in a small scale. Tellus 56A, 287-295.

Savijärvi, H. and Jin, L.-Y. 2001. Local winds in a valley city. BoundaryLayer Meteor. 100, 301-319.

Savijärvi, H. and Matthews, S. 2004. Flow over small heat islands: a numerical sensitivity study. J. Atmos. Sci. 61, 859-868.

Savijärvi, H., Niemelä, S. and Tisler, P. 2005. Coastal winds and low level jets: simulations for sea gulfs. Quart. J. Roy. Meteor. Soc. 131, 625-637.

Savijärvi, H. 2009. Stable boundary layer: model parameterizations for local and larger scales. Quart. J. Roy. Meteor. Soc. 135, 914-921.

Smedman, A.-S., Bergström, H. and Högström, U. 1995. Spectra, variances and length scales in a marine stable boundary layer dominated by a low level jet. Boundary-Layer Meteorol. 76, 211-232.

Stull, R. B. 1988. An Introduction to Boundary Layer Meteorology. Kluwer, Dordrecht.

Zilitinkevich, S., Perov, V. L. and King, J. 2002. Near-surface turbulent fluxes in stable stratification: calculation techniques for use in generalcirculation models. Quart. J. Roy. Meteor. Soc. 128, 1571-1587.

Walsh, J. E. 1974. Sea-breeze theory and applications. J. Atmos. Sci. 31, 2012-2026. 